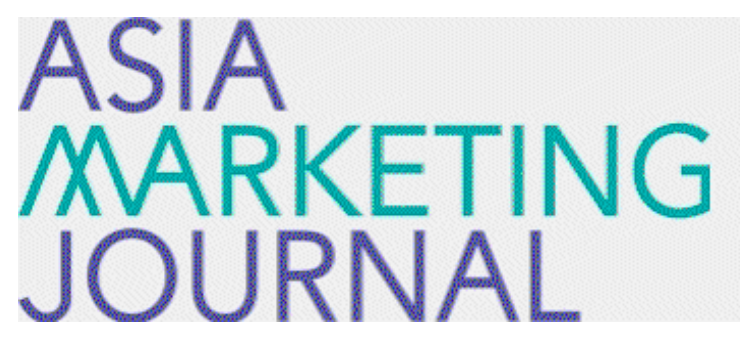

ASIA MARKETING JOURNAL

Volume 2 | Issue 4

Article 4

$12-1-2000$

\title{
구매접점에서 제공되는 부정적 정보가 소매점 매출 및 신뢰도에 미 치는 영향
}

In Soo Jeon

Kyong Chun Kim

Follow this and additional works at: https://amj.kma.re.kr/journal

Part of the Marketing Commons

\section{Recommended Citation}

Jeon, In Soo and Kim, Kyong Chun (2000) "구매접점에서 제공되는 부정적 정보가 소매점 매출 및 신뢰도에 미치는 영향," Asia Marketing Journal: Vol. 2 : Iss. 4 , Article 4.

Available at: https://doi.org/10.53728/2765-6500.1052

This Article is brought to you for free and open access by Asia Marketing Journal. It has been accepted for inclusion in Asia Marketing Journal by an authorized editor of Asia Marketing Journal. 


\title{
구매접점에서 제공되는 부정적 정보가 소매점 매출 및 신뢰도에 미치는 영향*
}

\section{An Effect On Store's Sales and Credibility of The Negative Information Offered at Point of Purchase}

\author{
전인수(훙익대학교 경영대학 교수) \\ jiss@wow.hongik.ac.kr
}

김경천 (훙익대학교 대항원)

kck2150@hanmail.net

\begin{abstract}
일반적으로 거래률 할 때 판매자는 자신에 유리한 정보를 구매자에게 제공하려 한다. 하 지만 자신에게 블리할 수 있는 정보률 제공하는 경우도 있는데, 이런 경우 과연 어떤 효과 가 있는지 궁금하다. 제공물에 관한 부정적 정보를 제공하는 방식은 여러 가지 있지만 본 연구에서는 톡히 최근 들어 그 중요성이 높아지고 있는, 구매접점에서 제공되는 것을 연구 과제로 정하였다. 또한 구매자가 제품의 품질을 알기 어려운 경우에 부정적 정보 제공의 효과가 선명하게 드러날 것으로 보아, 경협품질속성이 강한 사과를 대상으로 세 가설을 현 장실협으로 검중하였다. 그 결과 제공물의 중요한 속성에 관한 부정적 정보의 제공이 해당 제품의 매출에 부정적인 영향을 미치는 것으로 나타넜으며 구체적으로 사과 순매출감소율 이 27.6\%나 되었다. 또한 대체 제공물에 대한 유흑효과는 퉁계적으로 입중되지 않았으나 수치상으로 긍정적인 영향을 미치는 것으로 나타넜는데, 실험에서 딸기 순매출중가율이 $5.2 \%$ 이었다. 하지만 사과에 대해 잘 아는 소비자들의 점포에 대한 신뢰도 증가는 퉁계적으 로 유의하지 않았다. 연구결과로 미루어 인과스키마타에 어긋나는 정직한 정보의 제공으로 얻는 것이 별로 없으며, 약하지만 대체 제공물에서도 유혹효과가 나타난다는 점을 알 수 있다. 이렇기 때문에 판매자 입장에서 대체제품이 있는 경우, 특정제품에 대해 부정적 정 보를 제공하는 의미는 어느 정도 있다고 볼 수 있다.
\end{abstract}

* 논문접수: 01.04 게재확정: 01.05 


\section{1. 문제제기}

마케터가 자신에게 불리할 수 있는 정보를 고객에게 제공했울 때 고객은 어떤 반웅을 보 일까? 마케터에게 불리할 수 있는 정보, 즉 제공물의 단점과 관련된 정보인 부정적 정보는 자발적 방식과 비자발적 방식으로 제공될 수 있다. 담배나 의약품의 부작용을 경고한 것은 비자발적 제공의 예이고, 양측메시지 광고나 구매접점(point of purchase)에서 판매자가 판촉 전술의 일환으로 부정적 정보를 제공하는 것은 자발적 제공에 해당한다. 이들 중 구매자의 의사결정이 이루어지는 구매접점에서 자발적으로 제공되는 부정적 정보가 중요한데, 그 이 유는 최근 들어 구매접점이 고객만족의 결정적 순간(moment of truth)으로 꼽히고(전인수, 배 일현2000), 점포내 의사결정 비율이 갈수록 높아지기 때문이다. Shimp(2000, p.244)에 따르면 제공물간의 차이가 점차 줄어 수퍼마켓의 경우 점포내에서 구매결정하는 비율이 $70 \%$ 이고 할인점에서는 $74 \%$ 로 그 비율이 매우 높아 구매접점 판촉이 보다 중요해지고 있다고 한다.

구매접점 판촉의 내용으로는 유리한 가격조건, 제공물의 장점 등 직접적 설득정보가 주류 를 이루고 있으나, 우리나라 소매점 현장을 조사한 결과 진실마케팅(truth marketing) 혹은 디 마케팅(demarketing)이라 불리는 간접적 설득정보도 제공되고 있었다. 진실마케텅 흑은 디마 케팅을 정확히 정의하고 있는 것은 아니지만 제공물의 단점을 말하기, 정확한 스펙이 없는 경우 경쟁상표 추천, 합리적 구매의 유도 둥을 지칭하는 내용으로 사용하고 있었다. 여기서 사용하는 디마케팅이란 용어는 $\operatorname{Kotler}(1997, \mathrm{p} .16)$ 가 "일시적 초과수요를 감소시키는 것"으로 정의한 디마케팅과는 그 의미가 다르다. 보다 정확히 말하면 실무에서 사용하는 디마케팅은 고객에 대한 배려마케팅이라고 할 수 있다. 우리나라 옛 애기에 지나가는 나그네가 우물가 에서 물올 청했을 때 버드나무 잎을 띄워주는 처녀의 정성이 바로 배려마케텅의 진수라고 할 수 있다. 하지만 본 연구에서는 진실마케팅이나 디마케팅의 의미가 아직 생소하고, 혼란 의 우려가 있어 "구매접점에서 제공되는 부정적 정보"란 일반명칭올 사용한다.

구매접점에서 제공되는 부정적 정보제공의 효과는 두 갈래로 추론할 수 있다. 먼저, 정보 제공의 독특성으로 인해 설득효과가 나타나 해당제품에 대한 구입이 늘어날 것으로 볼 수 있고, 반면에 부정적 정보로 인해 해당제품의 매출은 감소하지만, 유혹효과(attraction effect)로 인해 대체제품의 매출이 늘어날 것으로 생각할 수 있다. 다음으로, 매출의 변화와 관계없이 부정적 정보 제공자인 점포에 대한 신뢰성은 높아질 것으로 생각할 수 있다. 이러한 추론은 모든 상황에서 유효하다고 볼 수 없기 때문에 본 연구에서는 품질측정이 어려워 지각된 위 험(perceived risk)이 높은 제공물인 과일 중에서 사과를 실헙대상으로 이러한 추론을 검중하 려 한다. 요약하면, 본 연구의 목적은 판매접점에서의 부정적 정보제공이 해당제품의 매출, 대체 제공물의 매출, 그리고 정보 제공자의 신뢰도에 미치는 영향을 밝히는 것이다. 제공자 에게 블리하게 작용할 수도 있는 부정적 정보 제공의 효과에 대한 연구는 요즈음 세간에서 쟁점화 되고 있는 투명경영의 효과를 짐작하는 데도 큰 의의가 있을 것으로 생각된다.

Darby and Kami(1973)는 품질측정의 어려움을 나타내기 위해 제공물의 속성을 탐색품질 속 성(search quality attributes), 경험품질속성(experience quality attributes), 신뢰품질속성(credence quality attributes) 둥 세 가지로 나누고 있다. 탐색품질 속성이란 구입하기 전에 알 수 있는 속성이고, 경험품질 속성이란 사용해봐야 아는 속성이며, 신뢰품질 속성은 사용해봐도 모르 는 속성이다. 흔히들 사랍은 격어봐야 알고 보약은 먹어도 그 효과를 모른다고 하는데, 이는 일상생활 속에서 이야기 되는 품질속성의 예이다. 사과를 위시한 배나 수박은 먹어봐야 그 
품질울 알 수 있는 경헙품질속성이 높기 매문에 구매접점에서 제공되는 정보가 특히 중요 하다고 볼 수 있어 실헙대상으로 선정하였다. 하지만 사과의 품질도 종류나 산지 등으로 추 론할 수 있어 어느 정도의 탐색품질속성은 가지고 있기 때문에 경협품질속성이 강하다는 것 은 어디까지나 상대적이다.

\section{2. 이론적 배경}

\section{1. 인과스키마타에 어긋나는 정보제공의 효과}

Kelley(1973)의 귀인이론은 공변원칙(covariation principle)과 인과스키마타(causal schemata) 혹 온 인과기대(causal expectations)로 나누어진다. 판매자가 자기 제품이 최고라고 말하는 것처 럼 당연한 애기를 할 때, 즉 인과기대에서 벗어나지 않을 때 정보로서의 가치는 떨어진다고 한다(Friestad and Wright 1994, 1995). 그 이유는 자사 제품이 최고라고 하는 것은 당연한 편 견이라고 보아 할인원칙(discounting principle)이 작용하기 때문이다. 우리속담에 세 가지 거 짓말이 있다. "처녀 시집 안 간다", "장사 밑지고 한다", "노인 빨리 죽어야지" 둥이다. 이를 액면 그대로 믿는 사람이 없는 것은, 말하지 않더라도 자아보호편견내지는 자아중진편견이 작용했을 것으로 믿는 인과스키마타(causal schemata)가 이미 우리 머리 속에 존재하기 때문 이다. 그래서 오히려 "나 시집가고 싶어", “이것 팔면 1000 원 남습니다." "오래 살고 싶어"라 고 하는 사랍의 말에 더 믿음이 갈 수 있다.

이처럼 인과스키마타를 뛰어넘는 정보를 제공하면 오히려 설득효과가 클 수 있다. 요컨대, 판매자가 제품의 부정적 속성을 솔직하게 인정하면 자아보호편견이나 자아중진편견이 줄어 들게 되어 광고의 내용을 더 믿을 수 있기 때문이다(Wood and Eagly 1981). 물론 제품속성에 관한 부정적 정보의 제공이 제품에 대한 부정적 평가로 연결될 수도 있다. 그렇기 때문에 상대적으로 덜 중요한 속성은 부정적 정보로, 보다 중요한 속성에 대해서는 긍정적 정보로 제시하면 전체적인 상표평가는 높아진다고 한다(Etgar and Goodwin 1982). 또한 양측정보를 제 공하는 광고의 효과는 부정적으로 표현되는 속성이 다른 속성과 부정적으로 관련된다고 지 각될 때 커진다고 한다(Pechmann 1992). 이러한 인과스키마타에 어긋나는 정보제공의 효과는 기억중심선택보다는 자극중심선택을 하는 경우에 더 커지는데, 그 이유는 Feldman and Lynch(1988)의 접근성-진단성 모델(accessibility-diagnosticity model)로 설명할 수 있다. 판매접 점에서 제공되는 정보는 접근성에서 매우 높고, 소비자의 지식수준에 맞추어 제공할 수 있 기 때문에 진단성 또한 높을 수 있다. 과일과 같은 산물(produce)의 경우 상표가 없고, 경험 품질속성이 강하기 때문에 판매접점에서 제공되는 부정적 정보로 인한 효과가 특히 클 수 있다.

인과스키마타에 어긋나는 정보제공의 효과는 사랍의 내면 성향이나 톡징에서도 나타난다. 일반적으로 판매원은 말이 많고 게걸스럽고 외향적인 성격으로 알려져 있는데, 부끄러움을 타고 내성적인 성격의 판매원을 만나게 되면 오히려 설득이 더 눱게 된다고 한다(Kardes 1999, p.205). 이 경우 부끄러움을 타는 것이 예외적으로 클 때 효과적인데, 그 이유는 중분 원칙(augmenting principle)이 적용되기 때문이다. 


\section{2. 유혹효과}

소비자가 구매를 하기 위해 고려집합(consideration set)에 속한 대안을 비교평가하여 하나를 고를 때 어떤 대안에 대한 부정적 정보룰 구매접점에서 접하면 비교가 되는 다른 대안을 더 좋게 평가하는 유혹효과(attraction effect)가 나타난다(Lehmann and Pan 1994; Pan and Lehmann 1993). 이러한 유혹효과가 제품별로. 나타나는 것이 아니라 속성별로 나타나는 것이 상쇄대 조효과(tradeoff contrast effect)이다(Simonson and Tversky 1992). 이러한 유흑효과는 같은 고려집 단에 속한 대안들간에 나타나는 현상이기에, 같은 제품카테고리안의 대안들간에 나타날 수 있는 것으로 이때까지의 연구는 보고 있다. 본 연구에서는 대체 제공물간에도 유혹효과가 나타나는지 알아보려 하기 때문에 기존 연구를 그대로 원용하기는 어렵다. 다만, 대체 제공 물이라도 소비자가 고려집합에 넣어준다면 유흑효과가 있을 것으로 추론한다. 유흑효과는 일상생활 속에서 많이 볼 수 있는데, 혼히 판매원들은 경쟁상표의 단점을 애기하여 자사상 표를 좋게 평가하도록 유도한다.

\section{3. 고객만족이론에서 추론할 수 있는 효과}

고객만족과 관련된 이론은 일관성이론(consistency theory)과 동화대조이론(assimilation contrast theory)으로 나눌 수 있다. Olshavsky and Miller(1972)는 일관성이론에 근거하여 기대률 높여 일단 사고 나면 성과가 기대에 못 미치더라도 이로 인해 초래되는 인지부조화 (cognitive dissonance)를 없애려 품질을 높게 평가하여 만족하게 된다고 한다. 반면에 Oliver(1980)는 동화대조이론에 의해 고객만족을 설명하는 기대불확정모델(expectancy disconfirmation model)을 제시하고 있다. 이 모델에 의하면 기대한 성과에 실제성과가 부합하 는 경우 고객은 만족한다. 그렇기 때문에 오히려 기대가 낮을수록 만족할 가능성은 더 높아 판매점에 대한 긍정적 행동의지로 연결될 수 있다고 추론할 수 있다. 하지만 기대가 낮으면 구입하지 않아 매출이 줄어드는 문제가 있다.

\section{4. 정보제공자의 신뢰성 효과}

오디언스가 정보제공자의 정직성 및 객관성을 지각할수록 신뢰성(credibility)이 높아진다고 한다(Shimp, p.343). 정직성온 오디언스가 정보제공자의 동기를 어떻게 지각하느냐에 따라 달라지는데, 오디언스가 정보제공자의 동기를 자기이익을 추구하는 것으로 지각할수록 신뢰 성은 높아지지 않는다. 반면에 객관적이거나 자기이익 추구에 도움이 되지 않는다고 지각할 때 신뢰성은 높아지는데, 정직성과 객관성에 대해 보다 자세히 살펴보기로 한다.

먼저, 정직성은 "기회주의적 행동을 하지 않음"으로 정의될 수 있다. 정보편중시에 속임수 (guile)로 자기이익을 추구하는 것(self-interest seeking)을 기회주의적 행동(opportunistic behavior)이라 하며 속임수는 세 가지로 나누어진다(Griesinger 1990). 먼저, 부정직(dishonesty) 인데 이는 교환에 가치가 있는 정보를 공개하지 않거나 잘못 제시하여 이익을 추구하는 것 올 말하고 다옴으로, 불이행(infidelity)인데 이는 협약이나 관계를 어느 일방이 유리하기 때 문에 상대편에 대한 보상이나 대안의 제시 없이 일방적으로 폐기하는 것을 말한다. 끝으로, 책임회피(shirking)내지는 편숭(free-riding)인데 이는 지속적 관계에서 최선의 노력과 협조를 다하지 않는 것을 말한다. 이러한 기회주의적 행동올 하지 않는 것이 바로 정직성이다. 기회 
주의적 행동으로 인해 소비자가 느끼는 부담을 지각된 거래비용(perceived transaction cost)이 라 하는데, 거래 상대편의 그러한 행동을 알아차리기 어려울 때, 즉 모니터링(monitoring)이 어려울 때 지각된 거래비용은 높아진다고 한다(전인수 1992). 하지만 모니터링이 어럽더라도 기회주의적 행동을 하지 않는 경우가 있는데, 게임이론에 의하면 거래를 반복하거나 설혹 한번의 거래로 끝나더라도 그 명성이 또 다른 거래자에게 전달둴 때이다.

다음으로, 양측정보의 제공으로 정의되는 객관성이다. 제공할 상품의 장점으로 설득하는 방법이 있고, 제공할 상품의 장점뿐만 아니라 상품의 속성상 피할 수 없는 단점으로도 설 득할 수 있다. 전자와 같이 특정상품에 대한 지지주장을 일관되게 하는 것을 단측정보라 하 고, 후자와 같이 지지주장과 반박주장을 같이 하는 것을 양측정보라 하는데 그 효과는 상 황에 따라 다르게 나타난다고 한다(Kardes 1999,p.165). 특히, 양측정보의 효과는 피설득자의 상품에 대한 지식정도와 구매의지에 따라 다르게 나타난다. 톡정상표률 선호하며 자주 구매 하는 피설득자에게는 단측정보 설득방식이 보다 효과적인 반면 그 상표에 매력을 느끼지 못 하거나 친숙하지 않은 피설득자에게는 양측정보 설득방식이 보다 효과적이다. 또한 제품카 테고리에 대한 지식수준의 정도에 따라 태도가 다르게 나타나기도 한다(Faison 1961), 제품에 대한 지식수준이 낮을수록 다른 제품에 대한 고려를 기피하기 때문에 반박주장에 대한 의지 가 약하므로 단측정보 설득에 영향을 많이 받는데 반해, 제품에 대한 지식수준이 높올수록 단측정보 방식이 편향적이며 불공정하다고 느껴 다른 대안을 모색하는 경향이 높아 양측정 보 설득방식이 보다 효과적이라고 할 수 있다.

객관성과 정직성이 있는 정보의 제공자를 믿게 되어 신뢰성(credibility)이 높아지는 이유는 균형이론(balance theory)으로 설명할 수 있다. 처음에는 상대를 믿지 못하지만 상대가 객관적 이거나 본인에게 손실을 초래할 수 있는 말을 하면 일관성의 원칙 때문에 그 정보제공자를 신뢰하게 된다고 한다(Heider 1958).

\section{3. 연구가설 및 실험설계}

\section{1. 연구가설}

본 연구의 목적은 두 가지이다. 구매접점에서의 부정적 정보제궁(S)이 매출 및 점포 신뢰 도라는 소비자반웅(R)에 미치는 영향이 어느 정도인지를 알아보는 것이다. 먼저 매출효과와 관련하여 다옴과 같이 추론할 수 있다. 구매접점에서 예상치 않았던, 특히 판매자에게 손해 를 끼칠 수 있는 정보를 제공받게 되면, 정보제공자의 자기웅호편견이란 인과스키마타에서 벗어나기 때문에 설득효과가 높아 매츨에 별다른 영향을 미치지 못하거나 오히려 매출이 늘 어날 것으로 추론할 수 있다. 하지만 이러한 추론에는 문제가 있다. Etgar and Goodwin(1982) 의 논리에 따르면 중요하지 않은 속성에 관한 부정적 정보를 제공할 때 인과스키마타에서 벗어난 정보제공의 효과가 크다고 한다. 또한 Pechmann(1992)은 양측정보 제공의 효과는 부 정적으로 표현되는 속성이 다른 속성과 부정적으로 관련된다고 지각할 때 커진다고 한다. 예컨대, 벌레 먹은 과일이 농약을 안쳤기 때문에 더 값지다고 지각하는 경우이다. 그렇기 때 문에 제공물의 중요한 속성에 대한 부정적 정보 제공은 인과스키마타에 벗어나는 정보제공 의 효과가 없을 것으로 불 수 있다. 한편, Oliver(1980)의 기대뷸확정모델에 따르면 부정적 정 
보제공으로 인해 기대가 낮아지면 만족은 높아지겠지만 매출은 감소한다. 또한 Feldman and Lynch(1988)의 접근성-진단성 모델에 의하면 판매접점에서 제공되는 부정적 정보의 효과는 매우 클 것으로 추론할 수 있다. 이상의 이론적 추론을 통해 다음과 같이 가설을 설정한다.

가설1: 구매접점에서 제공되는 제공물의 중요한 속성에 대한 부정적 정보는 매출에 부정적 으로 영향을 미칠 것이다.

한편, $\operatorname{Kardes}(1999, \mathrm{p} .129)$ 의 논리에 따르면 어떤 제공물의 중요한 속성에 대한 부정적 정보 는 대체관계에 있는 다른 대안을 더 좋게 보게 하는 유혹효과(attraction effect)가 나타난다. 특히 농산물인 경우 상표가 없어 자극중심선택을 보다 많이 하며, 더구나 경헙품질속성이 높고, 구매접점에서 제공하는 부정적 정보는 Feldman and Lynch(1988)가 말하는 접근성과 진 단성이 높아 유혹효과가 더 클 것으로 추론하여 다음과 같이 가설을 설정한다.

가설2: 구매접점에서 제공되는 제공물의 중요한 속성에 대한 부정적 정보는 대체 제공물의 매출을 중가시킬 것이다.

다음으로 $\operatorname{Shimp}(2000, \mathrm{p} .343)$ 의 논리에 따르면 정보제공자가 전문성이 있고, 정직하고, 객 관적이라고 오디언스가 지각할수록 정보제공자의 신뢰성이 높아진다고 한다. 정직성이란 기 회주의적 행동(opportunistic behavior)을 하지 않는 것으로 정의되는데, 모니터링이 어려울수록 그 가치는 높다고 한다(전인수 1992). 그 이유는 소비자가 느끼는 심리적 부담인 지각된 거 래비용이 모니터링이 어려운 경우에 정직성으로 인해 더 많이 줄어들기 때문이다. 농산물은 상표가 없고, 경험품질속성이 높아 심리적 거래비용을 톡히 많이 느끼는 제공물이라 부정적 정보제공, 즉 정직성으로 인해 신뢰성은 보다 높아 질 것이다. 또한 양측정보의 효과(Kardes 1999, p.165)에 따르면 부정적 정보제공으로 인해 정보제공자의 객관성은 높아져 신뢰성은 보다 높아질 것이다. 다만 Faison(1961)의 논리에 따르면 양측정보의 효과는 제공물에 대한 지식정도에 따라 달라, 지식정도가 높을수록 양측정보의 효과는 크다고 한다. 이러한 이론적 추론에 근거하여 다음과 같이 가설을 설정한다.

가설3: 제공물에 대한 지식수준이 높율수록 구매접점에서 부정적 정보를 제공하는 점포에 대한 신뢰도는 높아질 것이다.

\section{2. 실험설계}

현장실헙(field experiment)으로 본 연구에서 제시한 세 가설을 검중하려 한다. 실헙집단은 한국까르푸의 서울, 경인지역 4개 점포(중계, 면목, 중동, 구월)로 하였고 통제집단으로 같은 지역에 있는 일산, 계산, 안양, 분당 4 개 점포로 정하였다. 현장실험의 어려움 때문에 어쩔 수 없이 연구자의 편의에 따라 두 집단을 나누었다. 연구자와 친분이 있어 실험에 기꺼이 웅해주는 점포를 실헙집단으로 하였고, 그렇지 않는 같은 회사의 점포를 퉁제집단으로 선정 하였기 때문에 표본선정의 오류률 피하기는 어렵다. 표현은 퉁제집단이라고 하지만 엄밀히 말하면 비교집단에 불과합을 미리 밝혀둔다. 실험은 4월 21 부터 23 일까지(금, 토, 일) 고객이 많이 몰리는 3일간에 걸쳐 <그림 3-1>과 같은 가로 $50 \mathrm{~cm}$, 세로 $30 \mathrm{~cm}$ 의 정보보드(information 
board)를 구매접점에 부착해놓고 진행하였다. 정보카드는 사과의 가장 중요한 속성인 맛에 대한 내용을 담고 있는데, 사과의 맛은 당도와 수분에 의해 결정된다. 전문가의 견해에 따 르면 가을에 수확한 사과의 당도는 11-12도이고 수분은 $85 \%$ 정도이지만, 저온창고에 보관하 였다 4월에 출시되는 사과는 당도가 9-10도 수분은 $80 \%$ 정도가 되어 맛이 떨어진다고 한다. 단, 사과의 가격, 산지, 종류는 구분하지 않고 사과 매대 전체를 실협대상으로 하였다.

<그립 3-1> 정보보드: 부정적 정보

1. 본 상품(사과)은 99 년 11 월 수확한 것으로 약 4 개월간 저은창고에 보관하였기에 수확 기 상품보다 당도가 비교적 떨어집니다.

(정상상품 당도 11 내지 12도 $\rightarrow$ 본 상품 9 내지 10도)

2. 본 상품(사과)은 수확기 상품보다 수분 함유율이 다소 떨어집니다.

(정상상품 $85 \% \rightarrow$ 본 상품 $80 \%$ )

실헙기간 중 혹시 고객이 이를 보지 못할 경우가 있을 것으로 우려하여 판매사원을 배치 하여 그녕 사려는 고객에게 정보보드를 보도록 권했다. 실험전후의 점포에 대한 신뢰도를 비교하려 실협점포당 50 명씩 직접면접으로 1 차와 2 차로 나누어 이를 조사하였다. 1 차 설문조 사는 실험 1 주일 전 4월 14 에서 16 까지 실시하였고, 2 차는 실험물에 고객이 노출된 후 구입 한 고객을 대상으로 실헙기간 3일간에 걸쳐 실시하였다. 하지만 실험진행 시에 문제가 생겼 다. 실험에 웅해주기로 약속한 구월점이 막상 당일에 도저히 참여할 수 없다고 하여 중계점, 면목점, 중동점 3 개 점포에서 실헙은 실시하였고, 가설검중에는 구월점을 제외한 150 명올 대 상으로 수집한 자료를 사용하였다. 한편 점포에 대한 신뢰도는 점포에 대한 긍정적 행동의 도까지 포함하는 것으로 정의하여 "나는 한국까르푸를 신뢰한다."와 같은 7점 리커트스케일 6 개 항목으로 측정하였다. 또한 사과품질 지식정도는 "나는 어떤 것이 맛있는 사과인지 잘 안다."와 같은 7점 리커트스케일 5 개 항목으로 측정하였다.

\section{4. 실혐결과 및 가설검중}

\section{1. 실험집단간의 일치성 확인}

현장실험에서 가장 문제되는 것이 실헙집단간의 일치성 문제이다. 요컨대, 1 차조사의 웅답 자와 2 차조사의 웅답자가 일치해야 실헙변수의 효과를 확인할 수 있는데, 본 실험은 현장실 험인 관계로 같은 웅답자를 대상으로 조사하는 것이 불가능했다. 차선책으로 1차 200명과, 2 차 150 명간의 인구퉁계변수를 비교한 결과 <표 4-1>과 같다. 두 웅답자 집단의 인구퉁계변 수가 상당한 차이를 보이고 있어 문제가 있는 것으로 생각할 수 있으나, 소매점의 생필품 고객은 대부분 정해진 상권내에서 정기적으로 내점하기 때문에 비록 표본의 수가 작더라도 대표성은 있는 것으로 볼 수 있다.

한편 점포 신뢰도 및 사과품질 지식정도를 측정하기 위해 만든 척도의 내적일관성을 확인 
하기 위해 신뢰성 분석을 하였다. 그 결과 점포태도 4 문항(최초 6 문항)의 알파계수가 .8547 이였고 사과품질 지식정도 3 문항(최초 5 문항)의 알파계수는 .7082 로 나타나 Nunnally (1967) 의 기준(초기연구 .5 내지 .6, 기존연구 .8, 웅용연구 .9)을 무난히 넘어서는 것으로 나타났다.

<표 4-1>1,2차 설문 웅답자 특성

$(\mathrm{n}=1$ 차 200,2 차 150$)$

\begin{tabular}{|c|c|c|c|c|c|}
\hline \multirow{2}{*}{ 특 성 } & \multicolumn{2}{|c|}{ 표본수 및 구성비:명(\%) } & \multirow[t]{2}{*}{ 특 성 } & \multicolumn{2}{|c|}{ 표본수 및 구성비:명(\%) } \\
\hline & 1 차 & 2차 & & 1 차 & 2차 \\
\hline $\begin{array}{l}\text { 가족의 수 } \\
2 \text { 인 } \\
3 \text { 인 } \\
4 \text { 인 } \\
5 \text { 인 } \\
6 \text { 인 이상 }\end{array}$ & $\begin{array}{l}22(11.0) \\
37(18.5) \\
96(48.0) \\
38(19.0) \\
7(3.5)\end{array}$ & $\begin{array}{l}16(8.2) \\
52(26.8) \\
90(46.4) \\
26(13.4) \\
10(5.2)\end{array}$ & $\begin{array}{l}\text { 연 령 } \\
20 \text { 대 } \\
30 \text { 대 } \\
40 \text { 대 } \\
50 \text { 대 } \\
60 \text { 대 이상 }\end{array}$ & $\begin{array}{l}48(24.1) \\
79(39.8) \\
60(30.1) \\
11(5.5) \\
1(0.5)\end{array}$ & $\begin{array}{l}24(12.4) \\
87(44.8) \\
68(35.1) \\
13(6.8) \\
2(1.0)\end{array}$ \\
\hline $\begin{array}{c}\text { 월 소득 } \\
200 \text { 만원미만 } \\
200 \sim 300 \text { 만원 } \\
300 ~ 500 \text { 만원 } \\
500 \text { 만원 이상 }\end{array}$ & $\begin{array}{l}64(32.0) \\
99(49.5) \\
27(13.5) \\
10(5.0)\end{array}$ & $\begin{array}{l}60(30.9) \\
107(55.2) \\
22(11.3) \\
5(2.6)\end{array}$ & $\begin{array}{l}\text { 직 업 } \\
\text { 전업주부 } \\
\text { 회사원 } \\
\text { 학생 } \\
\text { 자영업 } \\
\text { 기타 }\end{array}$ & $\begin{array}{l}60(29.8) \\
64(31.8) \\
16(8.0) \\
44(21.9) \\
17(8.5)\end{array}$ & $\begin{array}{l}75(38.7) \\
60(30.9) \\
3(1.6) \\
47(24.2) \\
9(4.6)\end{array}$ \\
\hline $\begin{array}{ll}\text { 성 별 } \\
\text { 여 } \\
\text { 남 }\end{array}$ & $\begin{array}{l}133(66.5) \\
67(33.5)\end{array}$ & $\begin{array}{l}116(59.8) \\
78(40.2)\end{array}$ & & & \\
\hline
\end{tabular}

\section{2. 부정적 정보제공이 사과 매출에 미치는 영향}

<표 4-2>는 실험집단과 통제집단간의 매출을 분석한 것이다. 실헙집단 중 구월점은 1 차 조사후 실험참여 거부로 실헙집단에 포함되지는 않으나 실험설계에 맞추어 자료는 정리했다. 실험은 4/21 4/23에 이루어졌지만 그 이전의 매출패턴을 보기 위해 실헙전 3주간의 금, 토, 일 동일한 기간 매출액을 비교한 자료가 <표 4-2> 및 <그립 4-1>과 같다. 실험전인 3기 3개 점포(실헙집단) 매출변화와 실험후인 4기 5 개 점포(구월점을 포함한 통제집단) 매출변화에 차이가 있는지를 알아보려 Mann-Whitney U Test를 한 결과 Z값이 -2.236, 유의수준(sig.) .025 으로 나타나 가설1은 지지되었다. 한편, 수치를 비교해본 결과 실험집단 3 개점 매출액의 합 이 440 만원으로 앞 주 매출 655 만원에 비해 $32.6 \%$ 가 감소하였고, 동기간 통제집단 매출액 합은 710 만원으로 앞 주 매출 748 만원에 비해 $5 \%$ 정도 감소하였다. 실험집단의 매출감소가 통제집단에 비해 $27.6 \%(32.6 \%-5 \%)$ 포인트가 높아 수치상으로도 볼 때 부정적 정보제공의 효 과가 뚜렷한 것으로 나타넚다. 한편, $27.6 \%$ 가 실험효과인지를 확인하기 위해 실험전 3 주간 실험집단과 통제집단의 매출흐룜을 비교해보았다. 1 주차에서 2 주차로 넘어오면서 매출이 전 체가 감소했지만 퉁제집단은 $-10.9 \%$, 실험집단은 $-9.4 \%$ 로 나타나 $1.5 \%$ 포인트의 차이를 보이 고 있다. 2 주차에서 3 주차로 넘어가면서 둘 다 중가했는데, 퉁제집단은 $+8.75 \%$, 실헙집단은 
$+13.1 \%$ 로 나타나 $4.35 \%$ 포인트의 차이룔 보이고 있다. 이러한 차이에 비해 $27.6 \%$ 포인트는 현격한 차이라 할 수 있어 구매접점에서의 부정적 정보 제공이 사과매출에 매우 큰 부정적 영향을 미치는 것으로 판단할 수 있다.

<그림 4-1> 실헙집단과 통제집단의 사과매출 변화추이 비교

$\rightarrow-$ 실 험 집 단 $\rightarrow-$ 통 제 집 단

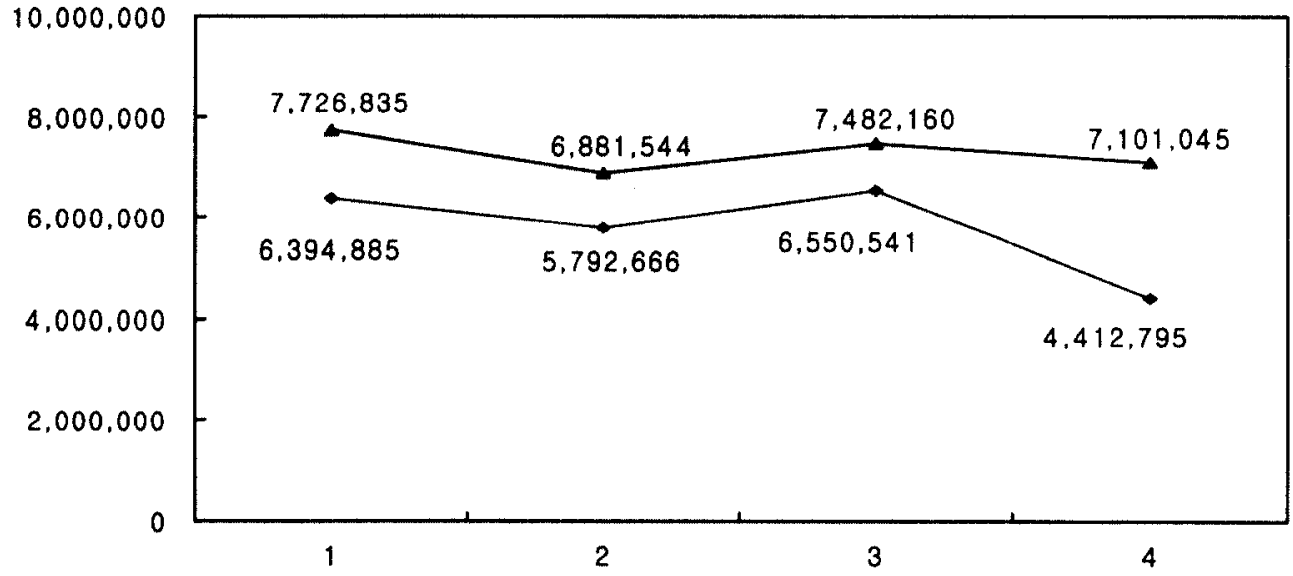

<표 4-2> 실험집단과 퉁제집단의 사과 매출액

\begin{tabular}{|c|c|c|c|c|}
\hline 매 지 강 & $3 / 31-4 / 02$ & $4 / 07-4 / 09$ & $4 / 14-4 / 16$ & $4 / 21-4 / 23$ \\
\hline 면 목 & $2,546,905$ & $2,406,230$ & $2,650,808$ & $1,935,431$ \\
\hline 중 동 & $1,642,470$ & $1,537,936$ & $1,681,779$ & $1,262,554$ \\
\hline 중 & $2,205,510$ & $1,848,500$ & $2,217,954$ & $1,214,530$ \\
\hline *구 월 & 739,130 & 480,600 & 732,265 & 715,530 \\
\hline 합 계 & $6,394,885$ & $5,792,666$ & $6,550,541$ & $4,412,795$ \\
\hline 일 & $1,597,382$ & $1,539,690$ & $1,804,770$ & $1,608,760$ \\
\hline 계 산 & $2,273,660$ & $1,793,155$ & $1,814,470$ & $1,750,945$ \\
\hline 안 양 & $2,129,243$ & $1,611,009$ & $1,825,230$ & $1,823,700$ \\
\hline 분 당 & $1,726,550$ & $1,937,690$ & $2,037,690$ & $1,917,640$ \\
\hline 합 계 & $7,726,835$ & $6,881,544$ & $7,482,160$ & $7,101,045$ \\
\hline
\end{tabular}

* 구월점의 매출액은 합계에서 제외

\section{3. 부정적 정보제공의 유혹효과로 인한 대체구매}

사과에 대한 부정적 정보제공으로 인한 유흑효과를 알아보려 실험시기에 대체관계에 있다 고 판단되는 과일인 딸기의 매출 변화를 확인해본 결과가 <그림 4-2>와 <표 4-3>에서 보는 바와 같다. 대체구매를 알아보려 딸기를 택한 이유는 해당매장의 관리자에 문의한 결과 일 반적으로 자기가 사려는 과일이 마음에 들지 않는 경우 제철 과일로 구입전환이 가장 많이 
일어난다고 했기 때문이다. <표4-3>의 자료를 바탕으로 실험전인 3기와 실험기간인 4기 3개 점포(실험집단) 사과매출의 변화와 봉제집단 5 개 점포(구월점 포함)의 매출변화에 차이가 있 는지 확인하려 Mann-Whitney U Test를 한 결과 Z값이 -1.342, 유의수준(sig.) .180으로 나타나 가설2는 지지되지 않았다. 하지만 구체적으로 어떤 변화가 있는지를 확인하려 수치를 비교 해본 결과 실험 전후의 매출변화를 보면 실험집단인 3 개 점포 매출합이 $+20.8 \%$, 통제집단인 4 개 점포 매출합이 $+15.6 \%$ 로 나타나 $5.2 \%$ 포인트 차이를 보인다. 이러한 차이가 실험효과인 지를 알아보려 이전의 매출변화를 점검해 본 결과는 다음과 같다. 1 주차와 2 주차를 비교해본 결과 둘 다 감소했고 실험집단 $-17.8 \%$, 퉁제집단 $-16.6 \%$ 였다. 2 주차와 3 주차를 비교해본 결 과 둘 다 감소했고 실험집단 $-9.2 \%$, 통제집단 $-11.1 \%$ 로 나타나 그 차이가 각각 $1.2 \%$ 포인트 와 $1.9 \%$ 포인트였다. 과거의 차이와 실험전후의 차이인 $5.2 \%$ 포인트를 비교해보면 부정적 정 보 제공으로 인한 유혹효과가 나타나 대체판매가 어느 정도 이루어진 것으로 짐작할 수 있 다. 하지만, 액수로 따져보면 대체효과가 567,900 원인데 반해 사과매출은 $1,803,668$ 원이 감 소하여 전체적으로 구매접점에서의 부정적 정보제공이 과일매출에 미치는 호과는 부정적이 라 말할 수 있다.

<그림 4-2> 실험집단과 퉁제집단의 딸기매출의 변화 추이 비교

\section{- 실험집단 홍제집단}

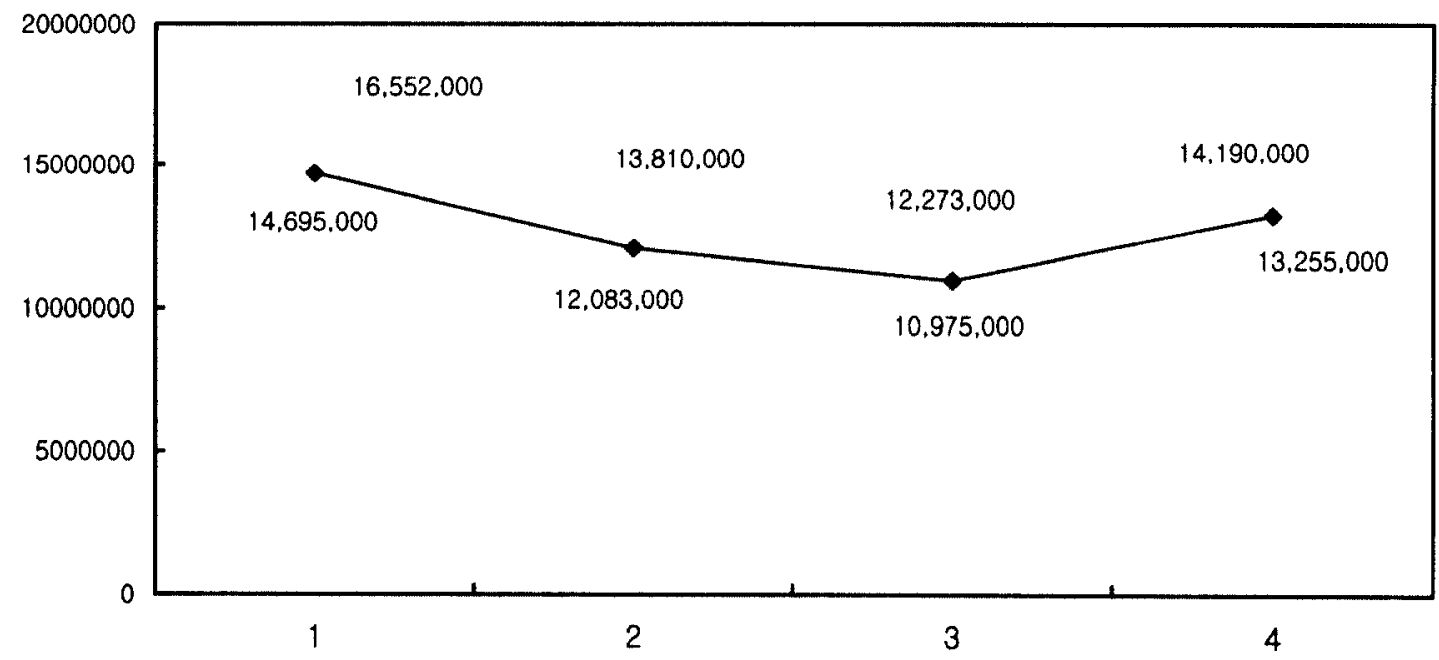

<표 4-3> 실헙집단과 통제집단의 딸기매출액

\begin{tabular}{|c|c|c|c|c|}
\hline 매 장 기 간 & $3 / 31-4 / 2$ & $4 / 7-4 / 9$ & $4 / 14-4 / 16$ & $4 / 21-4 / 23$ \\
\hline 면 목 & $5,639,000$ & $4,231,000$ & $3,800,000$ & $4,830,000$ \\
\hline 중 동 & $4,133,000$ & $3,820,000$ & $3,500,000$ & $4,100,000$ \\
\hline 중 & $4,923,000$ & $4,032,000$ & $3,675,000$ & $4,325,000$ \\
\hline *구 월 & $2,310,000$ & $2,010,000$ & $2,100,000$ & $2,310,000$ \\
\hline 합 & $14,695,000$ & $12,083,000$ & $10,975,000$ & $13,255,000$ \\
\hline
\end{tabular}




\begin{tabular}{|cl|l|l|l|l|}
\hline 일 & 산 & $3,350,000$ & $2,800,000$ & $2,875,000$ & $3,500,000$ \\
계 & 산 & $4,025,000$ & $3,505,000$ & $3,073,000$ & $3,200,000$ \\
안 & 양 & $4,375,000$ & $3,405,000$ & $3,250,000$ & $3,480,000$ \\
분 & 당 & $4,802,000$ & $4,100,000$ & $3,075,000$ & $4,010,000$ \\
\hline 합 계 & $16,552,000$ & $13,810,000$ & $12,273,000$ & $14,190,000$ \\
\hline
\end{tabular}

* 구월점의 매출액은 합계에서 제외

\section{4. 부정적 정보제공이 점포 신뢰도에 미치는 영향}

먼저 부정적 정보제공이 점포의 신뢰도에 미치는 영향을 알아보려 사과지식과 관계없이 실험전후의 점포에 대한 신뢰도 차이를 T-test로 알아보니 T값이 2.395이고, P값이 .017로 나 와 부정적 정보제공이 신뢰도에 긍정적 영향을 미치는 것으로 나타났다. 다음으로 본 연구 의 가설인 지식정도에 따라 어떤 영향을 미치는지를 알아보려 사과 품질지식 평균값올 중심 으로 두 집단으로 나누어 two-way ANOVA를 실시한 결과 <표 4-4>와 같다. <표 4-4>에서 알 수 있듯이 품질 파악여부와 부정적 정보제공의 효과는 있는 것으로 나타났으나 상호작용효 과는 있다고 하기 어려워 가설3은 지지되지 않았다. 이러한 정보률 <그립 4-3>과 같이 나타 낼 수 있는데, 상대적이지만 사과품질을 잘 아는 집단에서 그 효과가 약간 크게 나타나고 있으나 퉇계적으로 유의하지는 않다. 점포신뢰도 평균값의 중가를 보면 사과품질을 잘 아는 집단에서는 4.79 에서 5.10 으로 $6.5 \%$ 중가하였으며, 잘 모르는 집단에서는 4.36 에서 4.59 로 $5.3 \%$ 로 중가하였다. 단순히 수치를 비교할 것은 아니지만 매출감소가 $27.6 \%$ 인데 반해 신뢰 도 중가는 $6.5 \%$ 에 불과하여 재미있는 결과를 보이고 있다.

<표 4-4> 점포 신뢰도에 대한 two-way ANOVA

\begin{tabular}{|c|c|c|c|c|c|c|}
\hline 요인 & 중속변수 & 독립변수 & 자유도 & 자숭합 & $\mathrm{F}$ 값 & 유의수준 \\
\hline 주효과 & 신뢰도 & $\begin{array}{l}\text { 품질파악 여부 } \\
\text { 부정적 정보제공 }\end{array}$ & 1 & $\begin{array}{l}21.726 \\
6.750\end{array}$ & $\begin{array}{l}16.811 \\
5.223\end{array}$ & $\begin{array}{l}.000 \\
.023\end{array}$ \\
\hline $\begin{array}{l}\text { 상호작용 } \\
\text { 효과 }\end{array}$ & 신뢰도 & $\begin{array}{l}\text { 품질파악 여부 } \\
\text { 부정적 정보제공 }\end{array}$ & 1 & .166 & .128 & .720 \\
\hline
\end{tabular}

<그림 4-3> 점포 신뢰도의 변화

신뢰도

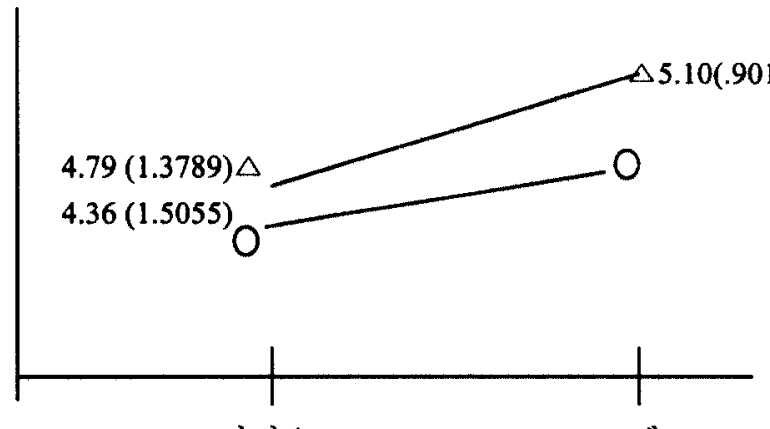

O: 사과품질을 잘 모르는 집단 $\triangle$ : 사과품질을 잘 아는 집단 


\section{5. 연구 결과 및 한계}

\section{1. 연구결과}

통계분석결과 가설 1 은 지지되었고, 수치를 비교한 결과 실험전후의 순매출변화(실헙집단 매출 증가율 - 뽕제집단 매출 중가율)가 $27.6 \%$ 로 나타나 판매접점에서 제공하는 부정적 정 보가 해당 제품의 매출에 부정적 영향 미치는 것으로 밝혀졌다. 반면 유흑효과로 인한 대체 제공물의 매출 변화를 알아보는 가설2는 지지되지 않았다. 다만, 수치상으로 볼 때 실험전후 의 순매출변화(실험진단의 딸기 매출변화 - 통제집단의 딸기 매출변화)가 $5.2 \%$ 로 나타나 퉁 계적 유의성은 없지만 긍정적 효과는 확인할 수 있었다. 한편, 실험전후 웅답집단이 동일하 지 않다는 문제점은 있지만, 간매접점에서 제공되는 부정적 정보가 점포의 신뢰도에 영향을 미친다는 가설3은 지지되지 않았다. 엄격한 통계적 절차를 거친 연구결과가 아니라 매우 조 심스럽지만 몇 가지 이론적, 실무적 의미는 제시할 수 있다.

먼저, 판매접점에서 제공하는 부정적 정보는 해당 제품의 매출을 $27.6 \%$ 나 감소시켜 인과 스키마타에 벗어나는 정보일지라도 그 정보가 어떤 내용이냐에 따라 그 효과가 다르다는 기 존의 이론과 부합한다. 즉, Etgar and Goodwin(1982), Pechmann( 1992) 등은 덜 중요한 속성은 부정적 정보를, 보다 중요한 속성에 대해서는 긍정적 속성을 제시하면 전체적인 상표평가는 높아진다고 하는데, 실험에서는 가장 중요한 사과의 두 속성인 당도와 수분과 관련된 부정 적 정보를 제공하였기 때문에 부정적 효과가 나타난 것으로 생각된다. 특히, Feldman and Lynch (1988)가 제시한 접근성-진단성 모델이 잘 적용되는 제공물에서 판매접점에서 제공되 는 부정적 정보의 효과가 크다는 것욜 알 수 있다. 또한 부정적 정보제공으로 인해 사과에 대한 기대가 낮아 만족은 높아질지 몰라도 매출은 오히려 감소하여 Oliver(1980)의 기대불확 정모델에 의한 설명과도 일치하는 것으로 해석할 수 있다.

다음으로, 대체 제공물인 딸기 매출 변화는 통계적으로 확인할 수 없었다. 다만, 딸기 순 매출중가가 $5.2 \%$ 로 유혹효과가 어느 정도 존재하는 것이 확인되었을 따름이다. 그 효과를 통계적으로 확인할 수 없었던 이유는 유혹효과(attraction effect)는 같은 계열 내 다른 품목에 잘 나타나기 때문인 것으로 추론할 수 있다. 하지만 대체 제공물에서도 어느 정도 나타날 수 있음을 확인한 것은 의미가 있는데, 유혹효과는 대체 제공물이라도 같은 고려집단 (consideration set)에 속하면 나타날 수 있음을 시사하고 있다.

셋째로, 지식정도에 따라 신뢰도가 달라질 것이라는 추론은 입중되지 않아 Faison(1961)의 연구결과와 일치하지 않았다. 다만, 신뢰도는 잘 모르는 집단에서 $5.3 \%$, 잘 아는 집단에서 $6.5 \%$ 씩 중가하였다. 이러한 결과가 나타난 이유는 여러 가지로 추론할 수 있다. 우선, 좋은 점과 나뽄 점올 동시에 제시해야 하는데 나쁜 점만올 강조하여 객관성을 높일 수가 없었고, 까르푸라는 점포전체의 정직성을 보여주기에는 사과가 너무 미약하였다고 볼 수 있다. 또한 우리나라 소비자는 인과스키마타에 어긋나는 애기를 의심하여 설득효과와 신뢰성효과가 없 는 것으로 추론할 수도 있다. 즉, 속아 살아 솔직함 그 자체를 의심하는지도 모른다.

넷째로, 이들 연구결과에서 얻을 수 있는 실무적 의미는 많다. 우선, 결정적으로 중요한 부정적 정보를 제공해서는 안된다. 요컨대, 앞에서 예를 든 것처럽 솔직한 수준의 정보제공 인 진실마케팅이나 배려마케팅은 권장할만한 판매전술이라 할 수 있으나, 결정적으로 중요 한 속성은 큰 피해률 가겨을 수 있다. 다음으로, 실제로 여러 회사 제품을 판매하는 소매점 
은 특정 카테고리내의 어느 상표를 판매하더라도 상관없기 때문에 부정적 정보제공으로 신 뢰도를 높이면서 매출 손실은 피할 수 있다. 한편, 이러한 판매접점 전략을 상품 공급자에 대한 교섭력(bargaining power)을 높이는 수단으로 활용할 수 있다. 세 번째로, 속아서 산 사 람들은 정직함을 의심하여 인과스키마타에 어긋나더라도 설득효과가 일어나지 않기 때문에 판매원 교육훈련시에 이 점을 유념해야 할 것이다.

다섯째로, 이러한 연구결과를 바탕으로 연구자들은 다음과 같이 정직마케팅(honesty marketing)과 투명경영에 대해 제안한다. 정직마케팅은 판매 전후로 나누어 사전에 이루어지 는 투명마케팅(transparency marketing)과 사후에 이루어지는 회복마케팅(recovery marketing)으 로 나눌 수 있다. 구매접점에서 제공되는 부정적 정보제공은 투명마케팅에 해당하며, 회복마 케팅은 대중을 상대로 하는 리콜(recall)과 개인을 상대로 하는 애프터서비스로 나눌 수 있을 것이다.

끝으로, 요즘 우리언론에서 투명경영을 요구하고 있다. 이 연구결과로 볼 때 어떤 정보를 투자자에게 정직하게 제시하는 투명경영에 문제가 있다고 볼 수 있다. 즉, 이해관계자에게 제공하는 투명한 정보도 그 효과를 거둘 수 있는 대안이 없는 경우에 매우 위험할 수 있음 올 지적하고 싶다.

\section{2. 연구한계}

본 연구는 탐색적 연구이자 현장실헙을 하였기에 여러 가지 한계를 내포하고 있다. 실헙 집단과 통제집단을 구분하였으나 객관적 기준에 의해 나눈 것이 아니라 연구자들의 친분에 의해 동참할 수 있는 점포만을 실협집단으로 삼았다. 심지어 1차 조사에서 동참했던 구월점 은 워낙 매출이 작아 문책의 소지가 있다면서 막상 실험 날짜에 참여를 거부하였다. 또한 점포에 대한 신뢰도를 알아보는 조사에서 1차 조사 대상과 2차 조사 대상의 표본이 같다고 하기 어려워 가설 3 의 점중에 문제가 있다. 톡히 2차 조사는 부정적 정보률 보고서도 사과를 구입한 고객을 응답자로 하였기에 점포 신뢰도를 서로 비교하는데 문제가 있음을 시인한다. 현장실험 이기에 어쩔 수 없었다. 욕심을 내자면 2번 정도는 실헙변수에 노출되도록 했어야 하는데, 많은 비용을 투입했음에도 블구하고 실헙이 너무 힙들어 그렇게 하지 못한 아쉬움 이 남는다. 끝으로 가격, 종류, 산지 둥 탐색품질속성에 속하는 변수는 뿡제하고 실험을 하 였기 때문에 이들 변수를 실험변수에 포합시켰을 때 어떤 반웅을 보일지 다시 연구해볼 가 치가 있음을 밝혀둔다. 


\section{<참교문헌>}

전인수, 배일현(2000), "4P 스키마타를 넙어서: 갭 스키마타," r한국마케텅저널」, 제2권, 제 1 호, 65-82.

전인수(1992), "소비재 거래에 있어서의 거래비용이론의 적용에 관한 연구," r경영학연구」, 제2권, 제 1 호, 한국경영학회, 173-192.

Darby, M. R. and E. Karni(1973), "Free Competition and the Optimal Amount of Fraud," Journal of Law and Economics, 16(April), 67-86.

Etgar, M., and Goodwin, S.M.(1982), "One-Sided versus Two-Sided Comparative Message Appeals for New Brand Introductions," Journal of Consumer Research, 8, 460-465.

Faison, E.W.(1961), "Effectiveness of One-Sided and Two-Sided Mass Communications and Advertising," Public Opinion Quarterly, 25, 468-469.

Feldman, J. M. and J. G. Lynch(1988), "Self-Generated Validity and Other Effects of Measurement on Belief, Attitude, Intention, and Behavior," Journal of Applied Psychology, 73, 421-435.

Friestad, M., and Wright, P.(1994), "The Persuasion Knowledge Model: How People Cope with Persuasion Attempts," Journal of Consumer Research, 21, 1-31.

(1995), "Persuasion Knowledge: Lay People's and Researcher's Beliefs about the

Psychology of Persuasion," Journal of Consumer Research, 22, 62-74.

Griesinger, Donald W.(1990), "The Human Side of Economic Organization," Academy of Management

Review, 15(3), 478-499.

Heider, F.(1958), The Psychology of Interpersonal Relations, New York: Wiely.

Kardes, Frank R(1999), Consumer Behavior, New York: Addison Wesley.

Kelley, H.H.(1973), "The Processes of Causal Attribution," American Psychologist, 28, 107-128.

Kotler, Philip(1997), Marketing Management, 9th ed., New York: Prentice Hall.

Lehmann, Donald R. and Yigang Pan(1994), "Context Effect, New Brand Entry, and Consideration Sets," Journal of Marketing Research, 31(August), 364-374.

Nunnally, Jum C.(1967), Psychometry Theory, New York: McGraw-Hill.

Oliver, Richard L.(1980), "A Cognitive Model of the Antecedents and Consequences of Satisfaction Decisions," Journal of Marketing Research, 17(November), 460-469.

Olsavsky, Richard and John Miller(1972), "Consumer Expectations, Product Performance, and Perceived Product Quality," Journal of Marketing Research, 9(February), 19-21.

Pan Yigang and Donald R. Lehman(1993), "The Influence of New Brand Entry on Subjective Brand Judgements," Journal of Consumer Research, 20(June), 76-86.

Pechmann, C.(1992), "Predicting When Two-Sided Ads Will Be More Effective Than One-Sided Ads: The Role of Correlational and Correspondent Inferences," Journal of Marketing Research, 29, 441-453.

Shimp, Terence A.(2000), Advertising Promotion: Integrated Marketing Communications, 4th ed., New York: Dryden.

Simonson, Itamar and Amos Tversky(1992), Choice in Context: Tradeoff Contrast and Extremeness Aversion, Journal of Marketing Research, 29(August), 281-295.

Wood, W. and Eagly, A.H.(1981), "Stages in The Analysis of Persuasive Messages: The Role of Causal Attributions and Message Comprehension," Journal of Personality and Social Psychology, 40, 246-259. 